\title{
THE EFFICIENCY OF BIOLOGICAL CONTROL TREATMENTS OF CODLING MOTH (CYDIA POMONELLA L.) ON THREE DIFFERENT APPLE VARIETIES
}

\author{
Tomaš, V. ${ }^{1 *}$ - ŠImić, D. ${ }^{1}$ - MihaljeVIĆ, I. ${ }^{1}$ - Dugalić, K. ${ }^{2}$ - ViljevaC Vuletić, M. ${ }^{1}$ - \\ VuKOVIĆ, D. ${ }^{1}-$ ZDUNIĆ, Z. $^{1}$ - BARIĆ, B. ${ }^{3}-$ BRMEŽ, M. $^{4}$ \\ ${ }^{1}$ Agricultural Institute Osijek \\ Južno predgrađe 17, 31103 Osijek, Croatia \\ (phone: +385-31-515-539; fax: +385-31-515-539) \\ ${ }^{2}$ Food and Rural Affairs, Croatian Center for Agriculture \\ Svetošimunska cesta 25, 10000 Zagreb, Croatia \\ (phone: +385-1-462-9240; fax: +385-1-462-9241) \\ ${ }^{3}$ Faculty of Agriculture, University of Zagreb \\ Svetošimunska cesta 25, 10000 Zagreb, Croatia \\ (phone: +385-1-239-3777; fax: +385-1-231-5300) \\ ${ }^{4}$ Faculty of Agriculture in Osijek, J. J. Strossmayer University of Osijek \\ Vladimira Preloga 1, 31000 Osijek, Croatia \\ (phone: +385-31-554-801; fax: +385-31-554-853) \\ *Corresponding author \\ e-mail: vesna.tomas@poljinos.hr; phone: +385-31-515-539; fax: +385-31-515-539) \\ (Received 10 $0^{\text {th }}$ Oct 2017; accepted 12 $2^{\text {th }}$ Feb 2018)
}

\begin{abstract}
Codling moth (Cydia pomonella L.) is one of the most important apple pests which population is steadily growing. The aim of this study, conducted in Eastern Croatia, was to determine the efficiency of two biological preparations $\mathrm{CpGV}$ and kaolin clay compared with pyrethroids and control treatment. The preparations used in treatments were: 1) Cydia pomonella granulovirus (CpGV), 2) deltamethrin, beta cyfluthrin and alpha-cipemetrina, 3) kaolin, 4) control treatment, applying in two different methods of time control, on the three apple varieties 'Melrose', 'Jonagored' and 'Golden Delicious' clone B. The efficiency of the treatment 1 (CpGV) ranged from $78 \%$ to $95 \%$, of treatment 2 (pyrethroids) from $96 \%$ to 97\%, and treatment 3 (kaolin) - between 21.5 and 57\%. There was significant negative correlation between yield and damage $(\mathrm{r}=-07.56)$. Two methods of determining time control did not differ significantly. Variety 'Melrose' had the highest number of fruits damage in all three years and 'Golden Delicious' clon B the lowest number which can be related to the codling moth caterpillar affinity to a certain variety. It is very important to make the best choice of preparations in control and at the same time be sure of their positive effect on the environment and human health.
\end{abstract}

Keywords: $C p G V$, kaolin, pyrethroid, time of control, variety

\section{Introduction}

The apple is a fruit species with the highest number of control treatments in the world (Blommers, 1994). In Croatia, the total number of apple control treatments are around 15 and 25 against all diseases and pests, while the number of control treatment of codling moth ranges from 6 to 8 treatments during one growing season. Despite ecological concern about the harmful pesticides effects on the environment, control of phytophagous species is mostly based on the use of chemical control (Choinard et al., 2016; Iraqui and Hmimina, 2016; Tamošiūnas et al., 2014). In the orchard with use of insecticides with 
broad spectrum of action, the result is absence of useful entomofauna diversity (Ismail and Albittar, 2016; Blommers et al., 1987) which contributes to the reduction of natural phytopagous population with no harmful effects on the environment. Biological control incoroporates various aproaches called integrated pest management which combines a variety of pest control methods (Mahr et al., 2008). The biological control methods imply use of pheromones and mating disruption (Ciglar, 1998; Maceljski, 2002), natural predators and parasitoids (Lacey and Unruh, 2005) as well as use of biological control agents (CpGV - Cydia pomonella granulovirus and EpNS - entomopatogenic nematodes). Cydia pomonella granulovirus $(\mathrm{CpGV})$ was used for 30 years in the most European countries (Sauer et al., 2017) while in Croatia it was registered in 2011 when it is commercial use started. Microbial agent (CpGV) belongs to genus Granulovirus, family Baculoviridae (Crook, 1991). It is highly pathogenic for codling moth and for some related moth species (Luque et al., 2001) but harmless for nontarget organisms (Stara and Kocourek, 2003).

The research hypothesis was that biological preparation on the basis of baculovirus would provide satisfactory fruit quality (codling moth damage less than 1\%) as well as more ecologically acceptance than chemical preparations (pyrethroid treatment) while kaolin treatment would have less fruit damage than the control treatment. The second hypothesis was that monitoring of codling moth life stage in insect cage would be more accurate in determing the time control than the flight monitoring on pheromone traps. The third hypothesis was existence of codling moth affinity according to certain varieties. According to hypothesis the first aim of this study was to examine the efficiency of biological products in Eastern Croatia on the basis of CpGV and kaolin clay as well as efficiency of plant protection products from group of synthetic pyrethroids compared with control treatment. The efficiency of treatment is manifested through two characteristics: fruit damage from codling moth (\% damage), which is a direct indicator, and fruit yield. The second aim of this research was to determine the time of application using two methods: monitoring developmental codling moth stages in insect cage and using pheromone traps for codling moth and summing the effective temperatures. The third aim was to determine the affinity of codling moth to the tested varieties.

\section{Materials and methods}

\section{Study sites}

The experiment was performed at the orchard of Agricultural Institute Osijek, Eastern Croatia $\left(45^{\circ} 31^{\prime} 44,56^{\prime \prime} \mathrm{N}, 18^{\circ} 45^{\prime} 44,88^{\prime \prime} \mathrm{E}\right)$ during 2012-2014 in four different control treatments of codling moth (Cydia pomonella L.). In 2012 climatic conditions were less favourable for the apple production, because of period of negative temperatures down to $-6{ }^{\circ} \mathrm{C}$ during the phenological stage of development BBCH 5-59 when apple was in stage of floral balloons. Low temperatures caused a decrease in the apple yield for $50 \%$ in 2012. During 2013 and 2014 there were not similar extremes that could negative effect on the apple production. Climate data for this research was collected by weather stations which was located in the experimental orchard (Figs. 1, 2 and 3).

\section{The treatments}

Treatment 1 was based on biological product baculovirus (Granupom), used in a dose of $150 \mathrm{ml} / \mathrm{ha} / 1 \mathrm{~m}$ height, with the addition of $300 \mathrm{~g}$ sugar. Treatment 2 was based 
on the group of synthetic pyrethroids- beta-ciflutrin (Beta Baythroid EC 025) in a dose of $500 \mathrm{ml} \mathrm{ha}^{-1}$, deltametrin (Rotor $1.25 \mathrm{EC}$ ) in dose of $600 \mathrm{ml} \mathrm{ha}^{-1}$ and alfa-cipemetrin (Fastac $10 \mathrm{SC}$ ) in dose of $250 \mathrm{ml} \mathrm{ha}^{-1}$. Chemical preparations from group of synthetic pyrethroids were involved in this research because of expected good results in efficiency in codling moth control as well as comparisons with the efficiency of biological products. Treatment 3 was based on the kaolin clay (Cutisan) $15 \mathrm{~kg} \mathrm{ha}^{-1}$ according to manufacturer's recommendations for codling moth control. Treatment 4 was control or untreated plot. The experiment included three apple varieties 'Golden Delicious' clone B, 'Jonagored' and 'Melrose'. Growing form of trees was spindly bush. Experimental orchard was planted in 2005 on the vegetative rootstock MM106. Experimental orchard was on 0.4 ha and divided into four equal parts, which represents different codling moths control treatments. Each part, from each other was separated with protective zone of three trees. Experimental orchard was also divided through the whole length in two equal parts, left and right side with 60 trees in each side. Every side of the same control treatment represents different method of time control. Every block of four experimental parts in orchard contained 5 experimental trees in the row of each variety, in total there were three rows with all three varieties with 15 trees per time of control, 30 trees per treatment, 120 trees in all four treatments. In the left part of experimental orchard (which contained 60 experimental fruit trees per one method of time control), treatments were done on the basis of monitoring imago flight by pheromone traps (critical number (threshold) was 3-5 adults per trap in one day or in several days) and after catching critical number per trap started with summarizing effective temperature till sum of $90{ }^{\circ} \mathrm{C}$ (which represents time of hatching larvae-L1. In the other part of the experimental orchard (which contained another 60 experimental fruit trees), the treatments were done on the basis of controlling the pest biology in insect cage for first generation combined with Wildbolz method (Wildbolz, 1962) for other generations. This method is based on the regular summarizing the effective temperature starting from January 1. Caterpillar hatching started at sum $90{ }^{\circ} \mathrm{C}$ of effective temperatures. At the $100{ }^{\circ} \mathrm{C}$ of effective temperatures codling moth flight started. The effective sum of $610{ }^{\circ} \mathrm{C}$ is necessary for ending period of one codling moth generation. During the fruit harvest every experimental tree was harvested separately, fruits were placed in labelled boxes and 100 apples were randomly allocated from each tree according to EPPO standards (2004) for visual control of damage. A 1500 apples were examined per time of control on three varieties, 3000 fruits were examined per treatment in left and in right side of experimental orchard which represents different time of control. In total there were examined 12000 apples in all four treatments and in two different methods of time control. After visual inspection of 100 apples the damage based on the number of incoming and outgoing tunnels and wholes from caterpillars of codling moth was determined.

\section{Statistical analysis}

Statistical analysis was performed using $\mathrm{R}$ software ( $\mathrm{R}$ core team, 2013). Anova function from car package was used for factorial analysis of variance with four sources of variation: time of control, codling moth treatment, variety and replication. Agricolae package was used to calculate Tukey's honest significant difference (HSD) test at $\mathrm{P}<0.05$ level $\left(\mathrm{HSD}_{0.05}\right)$. 


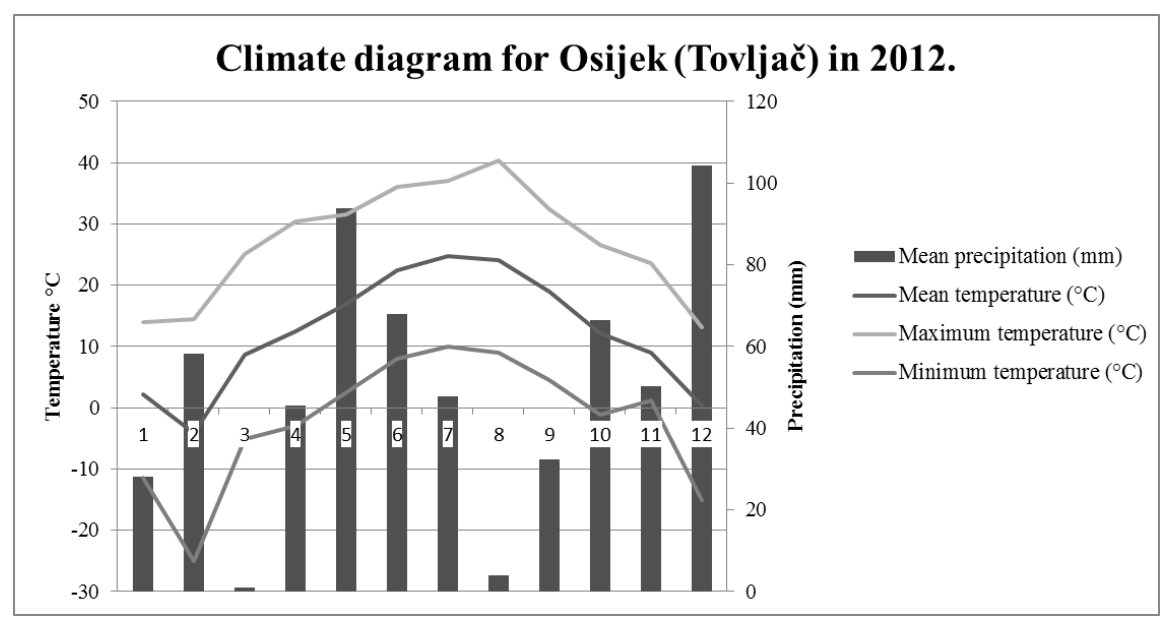

Figure 1. The monthly meteorological data for experimental orchard during 2012

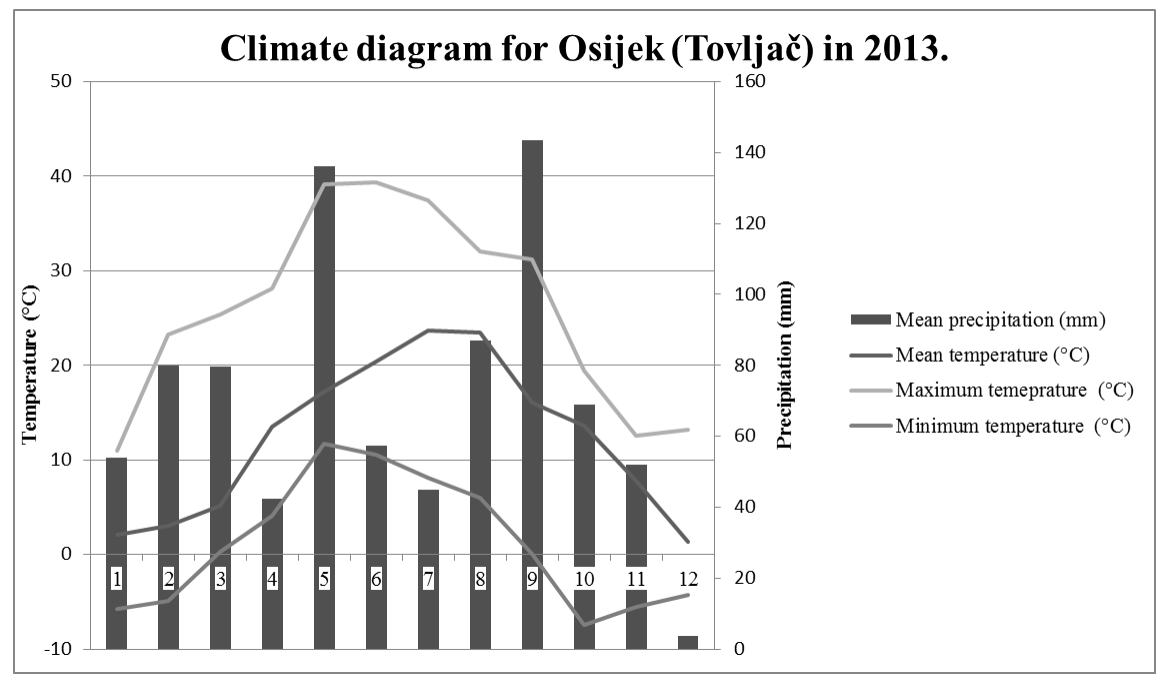

Figure 2. The monthly meteorological data for experimental orchard during 2013

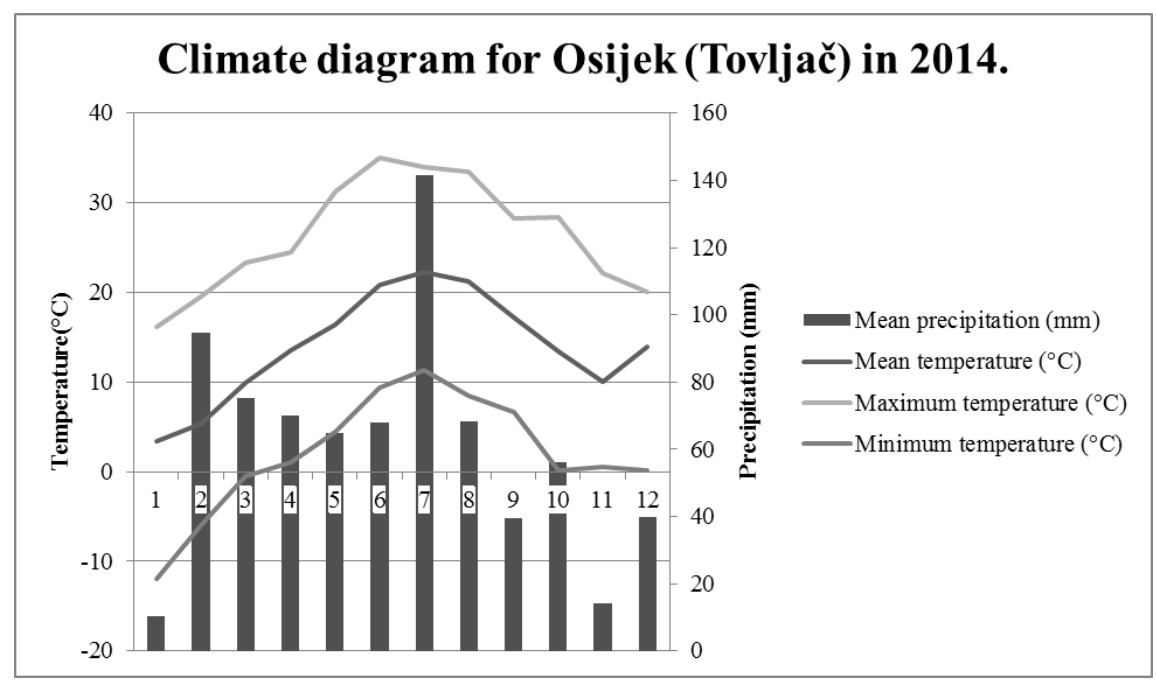

Figure 3. The monthly meteorological data for experimental orchard during 2014 


\section{Results}

Analysis of variance (ANOVA) revealed consistent non-significant effects of replication, time of control and interactions with time of control over the three years for both traits (Table 1). The effects of codling moth treatment and variety were mostly highly significant. The only significant interaction in the analysis was detected between codling moth treatment and variety for yield in 2013.

Table 1. Results of F-test from ANOVA for fruit yield and damage caused by codling moth (transformed data) in a three-factor design experiment conducted in Eastern Croatia over three years

\begin{tabular}{c|c|c|c|c|c|c|c}
\hline \multirow{2}{*}{ Source of variation } & \multirow{2}{*}{$\mathbf{d f}$} & \multicolumn{3}{|c|}{$\begin{array}{c}\text { Yield } \\
(\mathbf{k g})\end{array}$} & \multicolumn{3}{c}{$\begin{array}{c}\text { Damage } \\
\text { (\%-transformed) }\end{array}$} \\
\cline { 3 - 8 } & & $\mathbf{2 0 1 2}$ & $\mathbf{2 0 1 3}$ & $\mathbf{2 0 1 4}$ & $\mathbf{2 0 1 2}$ & $\mathbf{2 0 1 3}$ & $\mathbf{2 0 1 4}$ \\
\hline Replication (R) & 4 & 1.2 & 2.6 & 0.2 & 1.1 & 0.6 & 0.2 \\
Time of control (T) & 1 & 0.1 & 2.8 & 0.01 & 0.6 & 1.5 & 3.0 \\
Codling moth treatment (C) & 3 & $39.1^{* *}$ & $3.4^{*}$ & $22.0^{* *}$ & $574.9^{* *}$ & $1118.0^{* *}$ & $318.6^{* *}$ \\
Variety (V) & 2 & $4.0^{*}$ & $6.2^{* *}$ & $43.5^{* *}$ & $5.8^{* *}$ & $5.5^{* *}$ & $5.7^{* *}$ \\
$\mathrm{~T} \times \mathrm{C}$ & 3 & 0.7 & 1.5 & 2.1 & 0.01 & 0.04 & 0.1 \\
$\mathrm{~T} \times \mathrm{V}$ & 2 & 0.3 & 2.3 & 0.1 & 0.04 & 0.01 & 0.4 \\
$\mathrm{C} \times \mathrm{V}$ & 6 & 1.4 & $3.9^{* *}$ & 1.8 & 1.5 & 1.2 & 1.3 \\
$\mathrm{~T} \times \mathrm{C} \times \mathrm{V}$ & 6 & 0.8 & 1.4 & 0.6 & 0.1 & 0.04 & 0.5 \\
\hline
\end{tabular}

df - degrees of freedom, $* *$ - significant at the 0.05 and 0.01 probability levels, respectively

The separate analysis over three years are shown in Figure 4. demonstrating different mean values for fruit yield and damage across the codling moth treatment and variety. The pyrethroid treatment performed consistently the best results in comparison with baculovirus treatment and kaolin in all three tested years. Moreover, the differences between pyrethroid and baculovirus treatments were significant in all three varieties in 2012 and 2014 . The highest yield $(71.35 \mathrm{~kg})$ in 2013 and the lowest percentage of fruit damage $(1 \%)$ had variety 'Golden Delicious' clone B in the same treatment.

Combined ANOVA showed that fruit yield and damage differed significantly among treatments in all three years. The interactions between three codling moth damages and yield were significant in all three years of investigation. There were negative relations between the two traits with different association strengths across the three years (Fig. 5). The strongest association was in 2012 when the highest mean values for damage and the lowest mean values for yield were observed.

In the three-year field experiment, the highest average efficiency had treatment 2 with pyrethroids (96.6\%), followed by treatment 1 with $\mathrm{CpGV}(85.86 \%)$ and the lowest efficiency had treatment 3 with kaolin $(45.16 \%)$. The efficiency of pyrethroids was stable across the years (Table 2).

\section{Discussion}

Difference in yield between varieties among different treatments was expected because fruitfulness is not only result of intensity of pest infestation but genetic characteristics of each variety among other different but very important factors, such as 
fertilization, growth form, pruning, climate condition. In 2012, average yield of all three varieties were $19.11 \mathrm{~kg}$ which can be explained by the influence of frost and low temperatures during beginning of apple flowering in this year (Fig. 4).
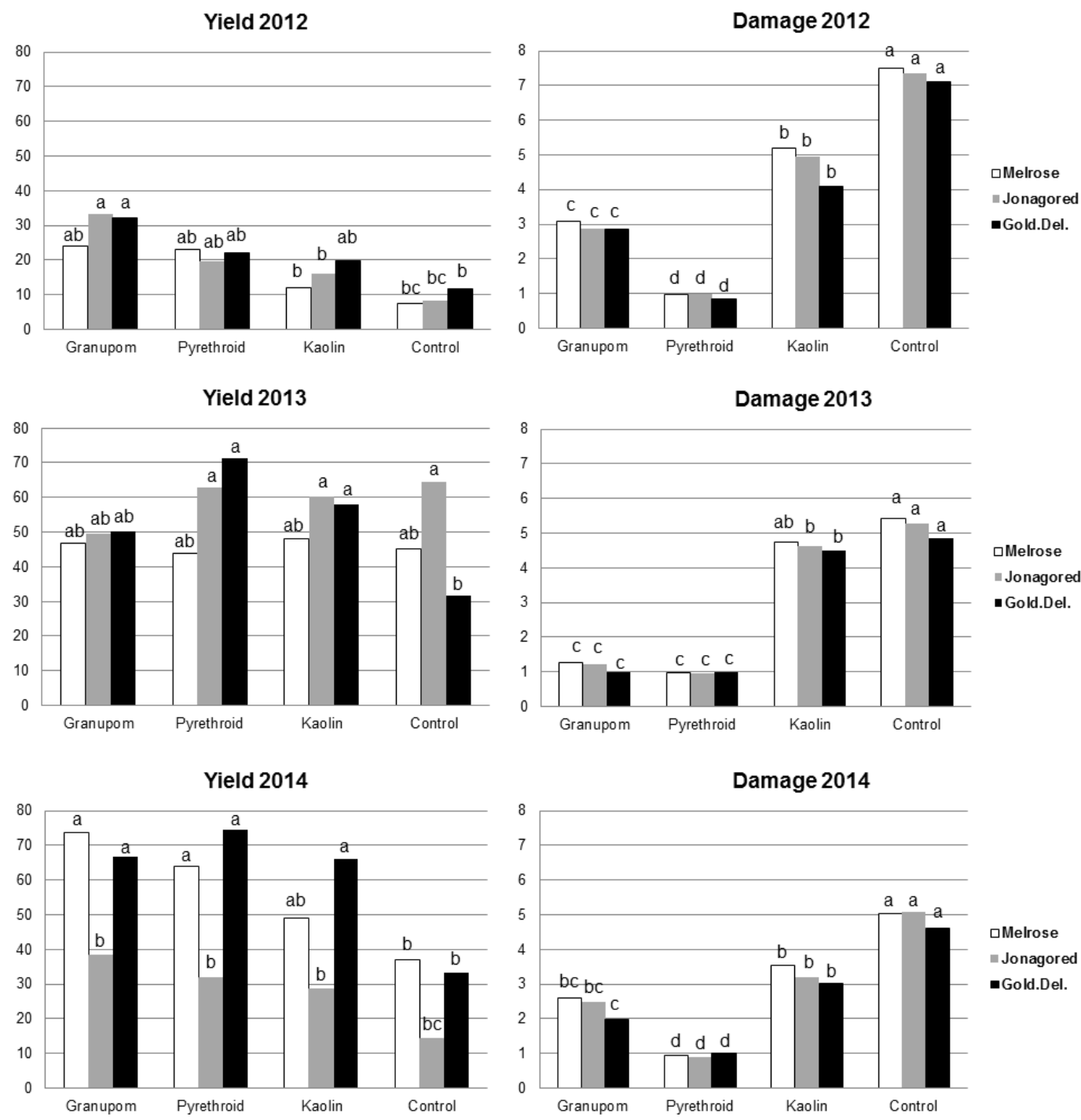

Figure 4. Mean values for fruit yield $(\mathrm{kg})$ and fruit damage (\%-transformed) in three apple varieties across three codling moth treatments and control averaged over two methods of time control of codling moth. Means with the same letters are not significantly different according to the Tukey's $H S D_{0.05}$

Table 2. Efficiency of applied treatments in the control of codling moth in 2012, 2013 and 2014 at locality Agricultural institute Osijek in Eastern Croatia

\begin{tabular}{c|c|c|c|c}
\hline \multirow{2}{*}{ Treatment } & \multicolumn{4}{|c}{ Efficiency \% } \\
\cline { 2 - 5 } & $\mathbf{2 0 1 2}$ & $\mathbf{2 0 1 3}$ & $\mathbf{2 0 1 4}$ & Average \\
\hline 1 (CpGV) & 84.60 & 95 & 78 & 85.86 \\
2 (pyrethroids) & 97 & 97 & 96 & 96.6 \\
3 (kaolin) & 57 & 21.5 & 57 & 45.16 \\
4 (control) & - & - & - & - \\
\hline
\end{tabular}




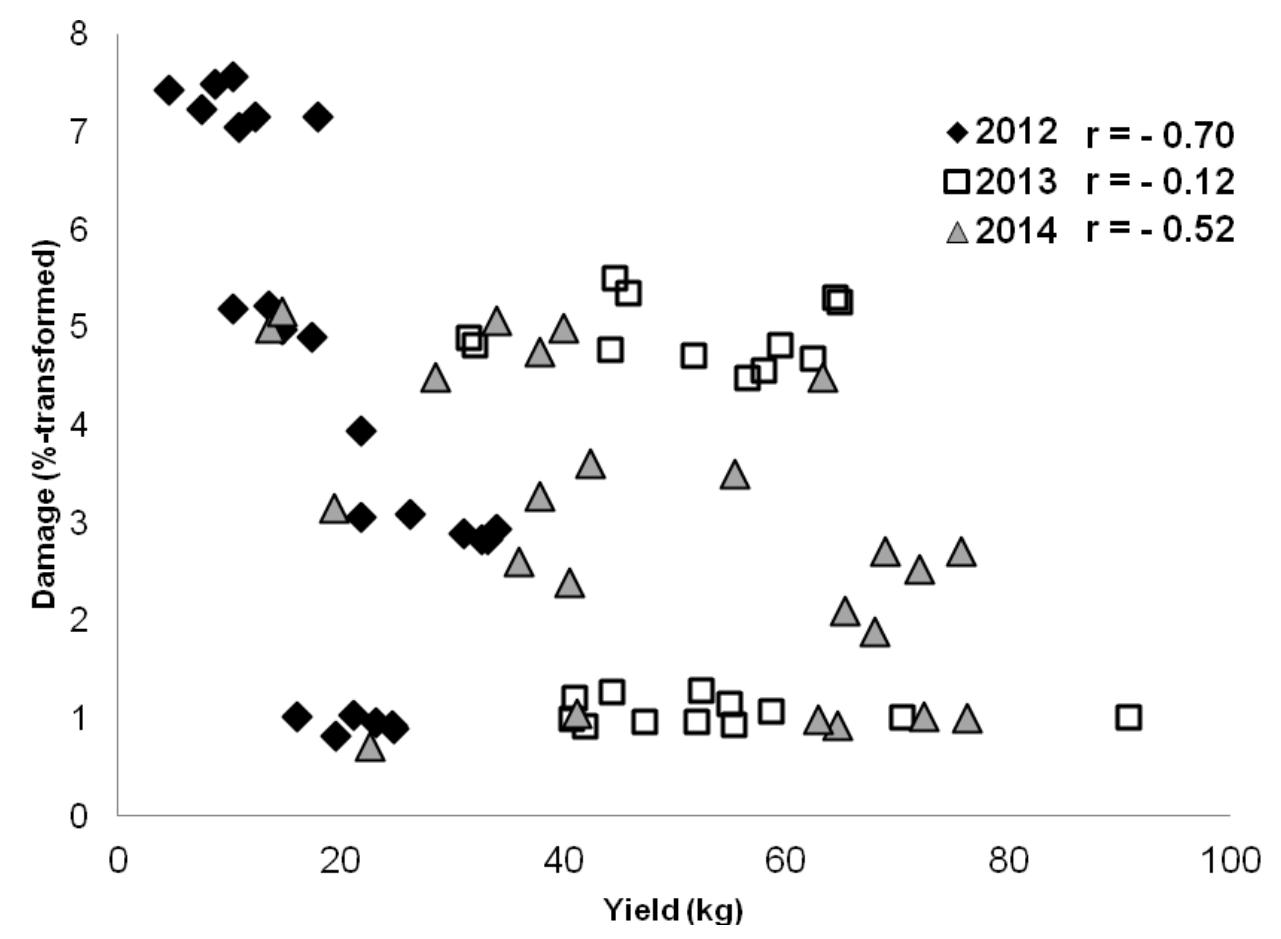

Figure 5. Relations between fruit yield and codling moth damage across the three years including all times of control, moth treatments and varieties. Note: Correlation coefficients (r) between the traits are indicated for specific year

A research in America showed that differences in annual fruit yield among three different production systems were inconsistent (Reganold et al., 2001). In this research damage on the apples from the codling moth was different between treatments and in the years of study. The higher percentage (more than 1\%) of fruit damage in treatment 1 $(\mathrm{CpGV})$, occurred due to short period of residual control which requires more frequent applications because of its sensitivity to solar radiation and its incapability to be exposure to UV radiation and extreme high temperatures (Arthurs and Lacey, 2004; Lacey and Arthurs, 2005). Baculovirus can persist for long periods in water and in the soil when is protected from sunlight and extreme high temperatures (Hajek et al., 2017). According to Wearing (1993), this virus has slow action and less efficiency in preventing codling moth damage. Results of early field efficiency trials showed that applications of $\mathrm{CpGV}$ are comparable to applications of chemical insecticides in their ability to control codling moth apple damage (Huber and Dickler, 1977; Mantinger et al., 1992). The best results with lowest percent of apple damage were in treatment 2 (pyrethroids). Conventional production in apple orchard results with little damage at harvest period (Suckling et al., 1999) but frequent insecticide applications are harmful to human health, the environment and beneficial organisams (Pajač et al., 2011). The most similar results in fruit damage with control had treatment 3 which included use of kaolin clay as shown in Fig. 5. According to Unruh et al. (2000), reduced number of codling moth damage was noticed on the apple fruits with kaolin film in compare with the control results. Kaolin clay particles do not kill pests but repellent them or act as barrier (Glenn, 2016; Glenn et al., 2002; Showler and Sétamou, 2004; Lapointe, 2000). Unruh et al. (2000) stressed that film of kaolin clay particles on fruits are very good protection against pest but only when their population is very low. 
In this study, a highly significant negative correlation between yield and fruit damage was recorded. A study in the US also showed that fruit damage of codling moth was negatively correlated with yields so that in years of low crop damage percentage was relatively high, while in years of high yield percentage of damage was relatively low (Clark and Gage, 1997). This occurred because the same population of codling moth, in the years of smaller yield, had a smaller amount of available food. Combined analysis of variance showed highly significant differences between the years of research, considering the yield and apple fruit damage from codling moth. Less significance occurred in the source variation treatment $\times$ time of control $\times$ variety. This indicates that climate has great impact on the yield and fruit damage, and that the year is the most critical factor in production of apples. In the same conditions of apple production, using the same treatments, time of control and varieties, characteristic of yield has very low repeatability. Correlation between yield and fruit damage was negative and significant $(P<0.01)$, and increasing damage on the apples from codling moth reduces yield.

Results of conducted research in treatment $1(\mathrm{CpGV})$ were similar to the results of efficiency from Czech Republic which varied from 75.5 to $96 \%$ (Stara and Kocourek, 2003). In Germany, the efficiency of CpGV was $70 \%$ (Kienzle et al., 2002). The reason for reduced efficiency could be because of use $\mathrm{CpGV}$ preparations for many years (Arthurs et al., 2004).

Treatment 2 (pyrethroids) efficiency varied from 96 to $97 \%$ while results of cypermethrin efficiency from Serbia varied from 92.2 to $97.6 \%$ (Miletić et al., 2011). Pyrethroids still have good efficiency but they also have broad spectrum of impact on beneficial insect so it is reason of limited number of applications during year season in integrated production.

The efficiency of treatment 3 (kaolin clay), varied between 21.5 and $57 \%$. The average efficiency in three years amounted to $45.16 \%$. This preparation is primarily used in orchards as protection from strong direct sunlight and to prevent the fruit surface sunburn (Glenn et al., 2002). In this study was shown that kaolin have effect on minimizing damage on the fruits from codling moth in comparison to control as confirmed by other studies (Showler, 2003; Knight et al., 2000; Unruh et al., 2000). Due to a low efficiency below $60 \%$, and its main effect in the prevention sunburns, should be included in the program of controlling first generation of codling moth (Knight et al., 2000) as well as additional product in an integrated control production. Statistical analysis did not confirm significant difference among different methods of calculating time control of Cydia pomonella and yield as well as fruit damage. It seems that both methods of calculating time control are based on monitoring of codling moth biology getting therefore equal results. The different number of fruit damages between varieties within the same treatment gives the conclusion of bigger or less attraction of codling moth caterpilar for certain variety The similar conclusion was made according to other authors (Hussain et al., 2014; Wenninger and Landolt, 2011; Landolt and Guẻdot, 2008). Biological control can be effective, economical and safe and it should be more widely used than it is today (Mahret al., 2008).

\section{Conclusions}

1. The Cydia pomonella granulovirus $(\mathrm{CpGV})$ based preparation had a lower average efficiency, $88.86 \%$, compared to the preparations from the group of synthetic pyrethroids and was with $4.88 \%$ average fruit damage in the treatment. The kaolin 
preparation had an average efficiency of $45.16 \%$ with $17.99 \%$ average fruit damage. Both preparations should be used in codling moth control program because of their positive impact on environment and human health. 2. Efficiency of two methods of determing control time did not differ significantly. Both methods showed equally good results.

3. Varieties in the study showed statistically significant differences in yield and fruit damage in all years of study. 'Melrose' had the highest number of fruits damage in all three years which can be related to the codling moth caterpillar affinity to a certain variety, than came 'Jonagored' and least attracti was 'Golden Delicious' clone B. It can be concluded that the affinity of codling moth to apple fruit is stronger when fruit surface has dominant red coloration and in this case further investigation is required.

\section{REFERENCES}

[1] Arthurs, S., Lacey, L. A. (2004): Field evaluation of commercial formulations of the codling moth granulovirus: persistence of activity and success of seasonal applications against natural infestations of codling moth in Pacific Northwest apple orchards. Biological Control 31(3): 388-397.

[2] Blommers, L. H. M. (1994): Integrated pest management in European apple orchards. Annual Review of Entomology 39: 213-241.

[3] Blommers, L., Vaal, F., Freriks, J., Helsen, H. (1987): Three years of specific control of summer fruit tortix and codling moth on apple in the Netherlands. - Journal of Applied Entomology 104: 353-371.

[4] Chouinard, G., Firlej, A., Cormier, D. (2016): Going beyond sprays and killing agents: Exclusion, sterilization and disruption for insect pest control in pome and stone fruit orchards. - Scientia Horticulturae 208: 13-27.

[5] Ciglar, I. (1998): Integrirana zaštita voćnjaka i vinograda - [Integrated Pest Management in Orchards and Vineyards]. - Zrinski, Čakovec, Croatia.

[6] Clark, M. S, Gage, S. H. (1997): Relationship between fruit yield and damage by codling moth and plum curculio in a biologically-managed apple orchard. The Great Lakes Entomologist 30(4): 161-168.

[7] Crook, N. E. (1991): Baculoviridae: Subgroup B. Comparative Aspects of Granulosis Viruses. - In: Kurstak, E. (ed.) Viruses of Invertebrates, pp. 73-110. Marcel Dekker, New York.

[8] EPPO Standards (2004): Efficacy evaluation of plant protection product - insecticides and acaricides. Efficacy evaluation of insecticides. Cydia pomonella. - Bulletin OEPP/EPPO Bulletin 3: 4-6.

[9] Glenn, D. M. (2016): Effect of higly processed calcined kaolin residues on appleproductivity and quality. - Scientia Horticulturae 201: 101-108.

[10] Glenn, D. M., Prado, E., Erez, A., Puterka, G. J. (2002): A refelective, processed - kaolin particle film affects fruit temperature, radiation and solar injuri in apple. - Journal of the American Society for Horticultural Science 127: 188-193.

[11] Hajek, A. E., Shapiro-Ilan, D. I. (2017): Ecology of Invertebrate Diseases. - Wiley, New York.

[12] Huber, J., Dickler, E. (1977): Codling moth granulosis virus: Its efficiency in the field in comparison with organophosphorus insecticides. - Journal of Economic Entomology 70: 557-561.

[13] Hussain, B., Ahmad, B., Bilal, S. (2014): Monitoring and mass trapping of the codling moth, Cydia pomonella, by the use of pheromone baited traps in Kargil, Ladakh, India. International Journal of Fruit Science 00: 1-9. 
[14] Iraqui, S. E., Hmimina, M. (2016): Assessment of control strategies against Cydia pomonella (1.) in Morocco. - Journal of Plant Protection Research 56(1): 82-88.

[15] Ismail, M., Albitar, L. (2016): Mortality factors affecting immature stages of codling moth Cydia pomonella (Lepidoptera; Torticidae), and the impact of parasitoid complex. Biocontrol Science and Technology 26(1): 72-85.

[16] Kienzle, J., Schulz, C., Zebitz, C. P. W., Huber, J. (2002): Persistence of the biological effect of codling moth granulovirus in the orchard preliminary field trials, p. $244 .-10^{\text {th }}$ International Conference on Cultivation Technique and Phytopathological Problems in Organic Fruit-Growing and Viticulture 2002. Weinsberg, Germany.

[17] Knight, A. L., Unruh, T. R., Christanson, B. A., Puterka, G. J., Glenn, D. M. (2000): Effects of kaolin based particle film on the oblique banded leafroller (Lepidoptera: Torticidae). - Journal of Economic Entomology 93(3): 744-749.

[18] Lacey, L. A., Arthurs, S. P. (2005): New method for testing solar sensitivity of commercial formulations of the granulovirus of codling moth (Cydia pomonella, Torticidae; Lepidoptera). - Journal of Invertebrate Pathology 90: 85-90.

[19] Lacey, L. A., Unruh, T. R. (2005): Biological control of codling moth (Cydia pomonella, Lepidoptera; Torticidae) and its role in integrated pest management, with emphasis on entomopathogens. - Vedalia 12(1): 33-60.

[20] Landolt, P. J., Guẻdot, C. (2008): Field attraction of codling moths (Lepidoptera: Torticidae) to apple and pear fruit and quantitation of kairomones from attractive fruit. Annals of the Entomological Society of America 101(3): 675-681.

[21] Lapointe, S. L. (2000): Particle film deters oviposition by Diaprepes abbreviates (Coleoptera): Curculionidae. - Journal of Economic Entomology 93(5): 1459-1463.

[22] Luque, T., Finch, R., Crook, N., O'Reilly, D. R., Winstanley, D. (2001): The complete sequence of the Cydia pomonella granulovirus genome. - Journal of General Virology 82: 2531-2547.

[23] Maceljski, M. (1999): Poljoprivredna entomologija [Agricultural Entomology]. - Zrinski, Čakovec, Croatia.

[24] Mahr, D. L., Whitaker, P., Ridgway, N. M. (2008): Biological Control of Insects and Mites: An Introduction to Beneficial Natural Enemies and Their Use in Pest Management. - Extension Biological Control Programs, University of Wisconsin, Madison.

[25] Mantinger, H., Bosheri, S., Paoli, N. (1992): Bekämpfung des Apfelwicklers mit Granulovirus. - Obstbau-Weinbau 9: 253-255.

[26] Miletić, N., Tamaš, N., Graora, D. (2011): The control of codling moth (Cydia pomonella L.) in apple trees. - Zemdirbyste-Agriculture 98(2): 213-218.

[27] Pajač, I., Pejić, I., Barić, B. (2011): Codling moth, Cydia pomonella (Lepidoptera; Torticidae) - Major pest in apple production: an overview of its biology, resistence, genetic structure and control strategies. - Agriculturae Conspectus Scientificus 76(2): 8792.

[28] R Core Team. (2012): R: A Language and Environment for Statistical Computing. - R Foundation for Statistical Computing, Vienna, Austria. http://www.R-project.org/.

[29] Reganold, J. P., Glover, J. D., Andrews, P. K., Hinman, H. R. (2001): Differences in annual fruit yield were inconsistent among the three production systems but cumulative yields were similar for all three systems. - Nature 410: 926-930.

[30] Sauer, A.J., Fritsch, E., Undorf-Spalin, K., Nguyen, P., Marec, F., Heckel, D.G., Jehle, J.A. (2017): Novel resistence to Cydia pomonella granulovirus (CpGV) in codling moth shows autosomal and dominant inheritance and confers cross-resistance to different CpGV genome groups.-PLOS ONE 12(6); e0179157.doi: 10.137/journal pone. 0179157

[31] Showler, A. T. (2003): Effects of kaolin particle film on beet armyworm, Spodoptera exigua (Hubner) (Lepidoptera: Noctuidae), oviposition, larva feeding and development on cotton, Gossypium hirsutum L. - Agriculture, Ecosystems and Environment 95: 265-271. 
[32] Showler, A. T., Sétamou, M. (2004): Effects of kaolin particle film on selected arthropod populations in cotton in the lower Rio Grande Valley of Texas. - Southwestern Entomologist 29: 137-146.

[33] Stara, J., Kocourek, F. (2003): Evaluation of efficacy of Cydia pomonella granulovirus $(\mathrm{CpGV})$ to control the codling moth (Cydia pomonella L.) in field trials. - Plant Protection Science 39(4): 117-125.

[34] Suckling, D. M., Walker, J. T. S., Wearing, C. H. (1999): Ecological impact of three pest management systems in New Zealand apple orchards. - Agriculture, Ecosystems and Environment 73(2): 129-140.

[35] Tamošiūnas, R., Valiuškaité, A., Surviliené, E., Duchovskiené, L., Rasiukevičiūté, N. (2014): Variety-specific population density and infestation levels of apple sawfly (Hoplocampa testudinea Klug) in two differently managed apple orchards in Lithuania. Zemdirbyste-Agriculture 101(2): 205-214.

[36] Unruh, T. R., Knight, A. L., Upton, J., Glenn, D. M., Puterka, G. J. (2000): Particle films for suppression of the codling moth (Lepidoptera: Torticidae) in apple and pear orchards. - Journal of Economic Entomology 93(3): 737-743.

[37] Wearing, C. H. (1993): Control of codling moth with commercial preparation of codling moth granulosis virus, pp. 146-151. - Proceedings of the $46^{\text {th }}$ New Zealand Plant Protection Conference.

[38] Wenninger, E. J., Landolt, P. J. (2011): Apple and sugar feeding in adult codling moths, Cydia pomonella: Effects on longevity, fecundity and egg fertlilty. - Journal of Insect Science 11(1): 161.

[39] Wildbolz, T. (1962): Über die Möglichkeit der Prognose und der Befallsüberwachung und über Toleranzgrenzen bei der integrierten Schädlingsbekämpfung im Obstbau. Entomophaga 7: 273-278 (in German). 